\title{
Gait Analysis in Rotational Acetabular Osteotomy
}

\author{
Riki Ueki, Masamori Shigematsu, Tsutomu Motooka, \\ and Takao Hotokebuchi \\ Department of Orthopaedic Surgery, \\ Saga University, Saga, Japan
}

\begin{abstract}
A study on early weight-bearing after rotational acetabular osteotomy (RAO) was performed in our hospital. In this study, gait analysis was performed on 27 patients (all females; mean age 37 years, range 12-58 years) who underwent unilateral RAO between 1999 to 2003.

The gait was analyzed preoperatively and 3 weeks, 1, 3, 6, and 12 months postoperatively. All the patients underwent a "free" walking test on a 5 -m walkway having a ground reaction force plate (gait scan 8000; Nitta Inc.). The test was carried out for 5 seconds. Single and double support duration (\% cycle) was assessed. The normal average value in healthy humans reported by Murray et al. ${ }^{3)}$ was used during the assessment.

The preoperative single support duration was unchanged while the double support duration was increased when compared with that for a normal person. Three weeks post operation, single support duration showed increasing reduction while double support duration showed decreasing reduction. However, single support duration gradually attained the normal average value within 1 year. Double support duration attained the normal average value postoperatively. Thus, it can be concluded that the gait improved post RAO. These results concurred with other studies that also reported pre- and postoperativ results in patients with late weightbearing post RAO. Given these results, we believe gait characteristics remain unaffected post $\mathrm{RAO}$ if early weight-bearing is performed.
\end{abstract}

Key words : hip displasia（臼蓋形成不全症）, rotational acetabular osteotomy（寬骨臼回転骨切り 術), gait analysis (歩行解析)

\section{Introduction}

Hip dysplasia has a relatively high prevalence in Japan ${ }^{6)}$. Rotational acetabular osteotomy $(\mathrm{RAO})^{7)}$ is an interventional strategy that seeks to reduce the abnormal high stress concentration in the acetabulum and thereby to prevent the development of coxarthrosis. Good clinical and radiological long-term results of RAO have been reported ${ }^{588}$; however, the change in gait characteristics in patients post RAO is not well known. Particularly, there are few studies that report the observation of periodic changes in gait characteristics post $\mathrm{RAO}^{1)}$. Our department used a critical pathway for the patients who underwent RAO. Weight-bearing was performed 5 days post RAO. Gait analysis is a useful tool in the evaluation of locomotors function post various operations.

The purpose of this study was to evaluate gait adaptation post RAO. 


\section{Patients}

Twenty-seven patients (all females) who underwent unilateral RAO between 1999 to 2003 were evaluated using gait analysis in our hospital. None of the patients demonstrated any symptoms involving the contralateral hip, lumber vertebrae, knee, or ankle. The mean age of the subjects was 37 years (range 12-58 years) at the time of the operation. According to the stage classification for hip osteoarthritis, there were 14 patients in the early stage and 13 patients in the advanced stage. The patients did not demonstrate any other joint disability. No limitation of the hip motion was observed in any patient. The average duration of follow-up was 1 year and 2 months (range 1 month-4 years).

The average center-edge (CE) angle observed in the patients ws 5.7 and the acetabular-head index (AHI) was 55.8\%. Preoperatively, the patients had an average CE angle of 31.0 degrees and an AHI of $83.5 \%$.

According to our critical pathway, full weight-bearing was started on the 7th day postoperatively. All the patients were discharged with either a crutch or T-cane within 3 weeks post surgery. We did not recommend special rehabilitation requirement for any patient post discharge. The operative technique used was identical for all patients.

\section{Methods}

The gait was analyzed preoperatively and 3 weeks, 1, 3, 6, and 12 months postoperatively. All the patients were tested while "free" walking along a 5-m walkway having a ground reaction force plate (gait scan 8000; Nitta Inc.). Their walk was tested for 5 seconds. In this system, the distribution pattern of anti-power and sole pressure in relation to the time factor while walking, the distance factor, gait speed, and walk rhythm can be measured. During this study, the time factor, namely, the single and double support duration (\% cycle), was evaluated.

These values were evaluated pre- and postoperatively. Moreover, the difference in gait pattern and restorative progress was evaluated using the stage classification for OA.

The result was examined and compared with the data of healthy persons reported by Murray et al. ${ }^{3)}$

\section{Results}

1. Single support duration (\% cycle) (Fig. 1)

The average value for patients prior to RAO was unchanged when compared with that for a healthy person; however, it reduced to about 30\% 3 weeks post RAO. It increased gradually and attained the normal value within 1 year. Trendelenburg's sign was not observed in any patient until 6 months postoperatively.

2. Double support duration (\% cycle) (Fig. 2)

The average value for patients prior to RAO was higher than that for a healthy person. It increased to about 121\% 3 weeks post RAO; it reduced gradually and improved within 6 months postoperatively, attaining the normal average value within 1 year post RAO.

3. Early stage vs. advanced stage.

Prior to RAO, the patients were classified into advanced and early stages using the OA stage classification, and the change was observed immediately post RAO. According to the JOA score, the 


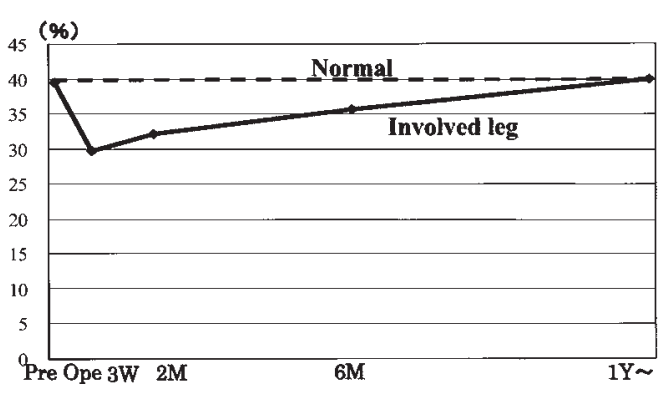

Fig. 1 Single support duration (\% cycle) The average value in patients did not change prior to RAO when compared with a healthy person. It decreased 3 weeks post RAO before gradually attaining the normal average value within 1 year post RAO.

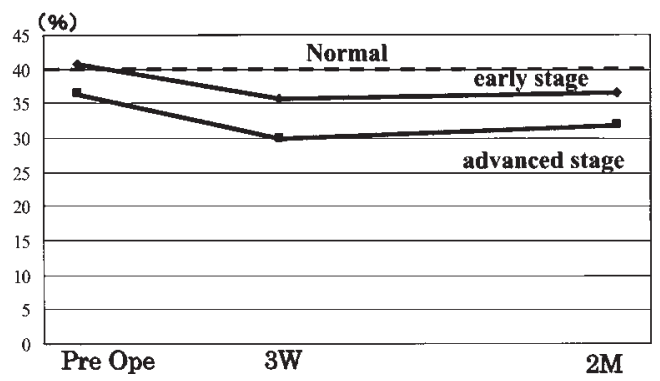

Fig. 3 Single support duration (\% cycle) The transition in single support duration post RAO was different for the early and advanced-stage groups.

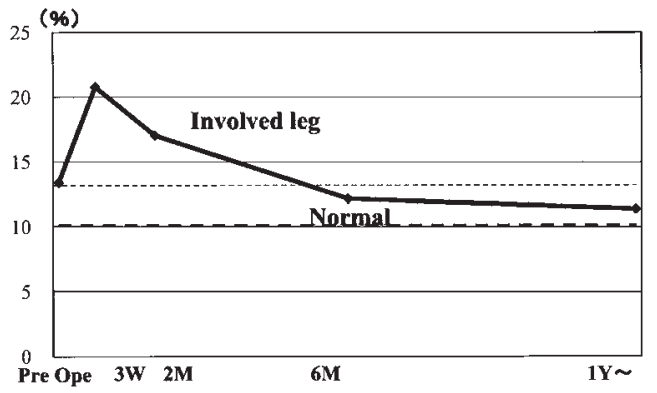

Fig. 2 Double support duration (\% cycle) The average value in patients prior to RAO was higher than that for a healthy person. It increased 3 weeks post RAO, but 6 months later was lower than the increased value recorded prior to RAO. It attained the normal average value within 1 year post RAO.

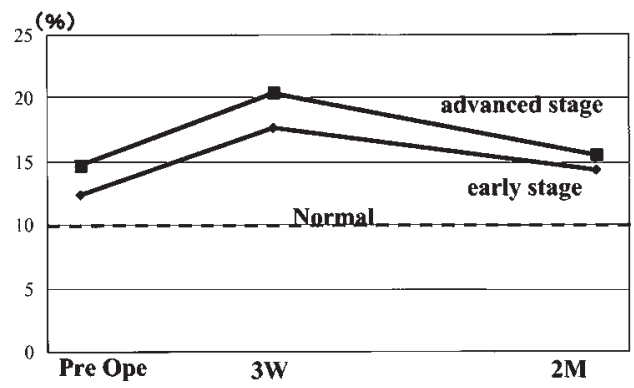

Fig. 4 Double support duration (\% cycle) The transition in double support duration post RAO was different for the early and advanced-stage groups.

preoperative average value of pain was 29 in the early-stage group and 15 in the advanced-stage group. - Single support duration (\% cycle) (Fig. 3)

In the early-stage group, single support duration prior to RAO was unchanged when compared with that for a healthy person. There were few decreasing rates observed post RAO. On the other hand, in the advanced-stage group, single support duration prior to RAO was lower than the normal average value. The rate at which single support duration decreased post RAO was higher than that observed in the early-stage group.

- Double support duration (\% cycle) (Fig. 4)

When compared with the advanced-stage group, double support duration prior to RAO in early-stage group was closer to the normal average value; however, the rate of increase in the double support duration post RAO was observed to be lower than that of the advanced-stage group. 


\section{Case Presentation}

\section{- Case 1}

A 23-year-old female complained of right hip pain, which was preoperatively classified as an earlystage OA. Preoperatively, the CE angle was 13 degrees, AHI was 51.1\%, and pain was 40 points (according to the JOA score). The CE angle post RAO was 35 degrees and AHI was 91.1\% (Fig. 5). Single support duration prior to RAO was $42 \%$. The decreasing rate of single support duration post RAO was low. Trendelenburg's sign disappeared within 3 months post RAO (Fig. 6). The increasing rate of double support duration post RAO was low. These values attained the normal average value 2 months post RAO (Fig. 7).

\section{- Case 2}

A 51-year-old female complained of right hip pain, which was preoperatively classified as an advanced-stage OA. Preoperatively, the CE angle was 3 degrees, AHI was 50\%, and pain was 20 points
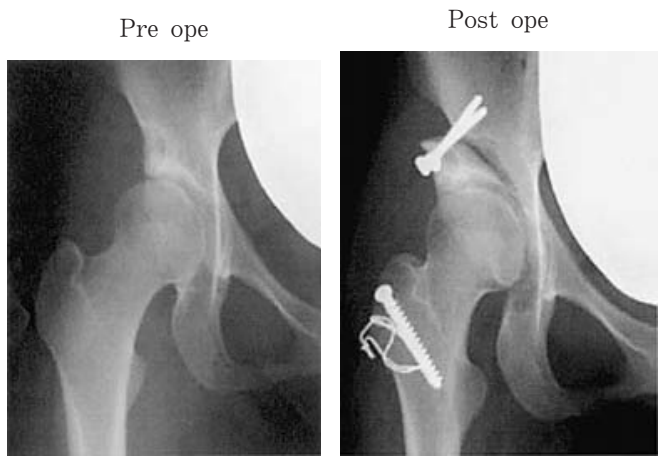

Fig. 5 Case 1. Plain X-ray radiographs of a 23year-old female revealed an early-stage OA. Preoperatively, the CE angle was 13 degrees, AHI was $51.1 \%$, and pain was 40 points (according to the JOA score). Postoperatively, the CE angle was 35 degrees and AHI was $91.1 \%$.

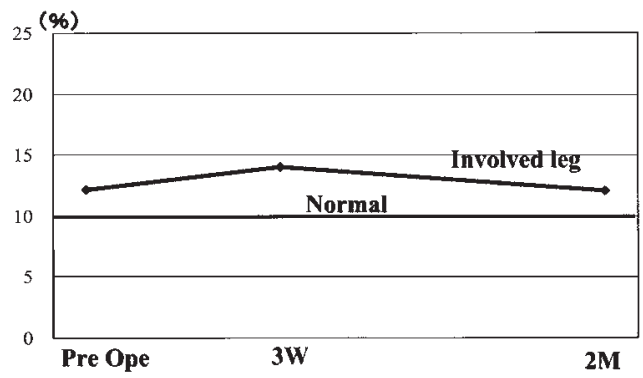

Fig. 7 Double support duration (\% cycle) The increasing rate of double support duration post RAO was low. Two months post RAO, it attained the normal average value.

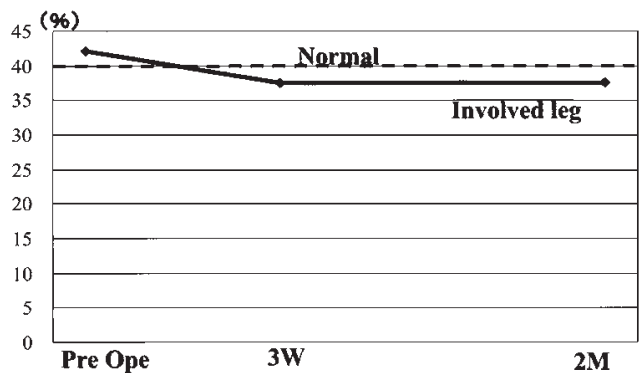

Fig. 6 Single support duration (\% cycle) Single support duration prior to RAO was $42 \%$. The decreasing rate post RAO was low.

Pre ope

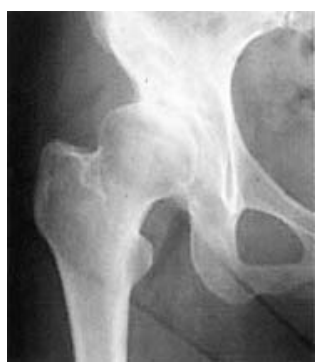

Fig. 8 Case 1. Plain X-ray radiographs of a 51year-old female revealed an advancedstage OA. Preoperatively, the CE angle was 3 degrees, AHI was $50 \%$, and pain was 20 points (according to the JOA score). Postoperatively, the CE angle was 30 degrees and AHI was $85.7 \%$. 


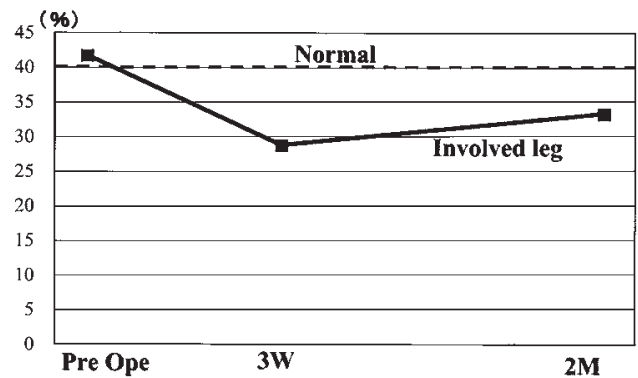

Fig. 9 Single support duration (\% cycle) Single support duration prior to the operation was $42 \%$. The decreasing rate was high post RAO and reduced to $29 \%$ before gradually attaining the normal average value.

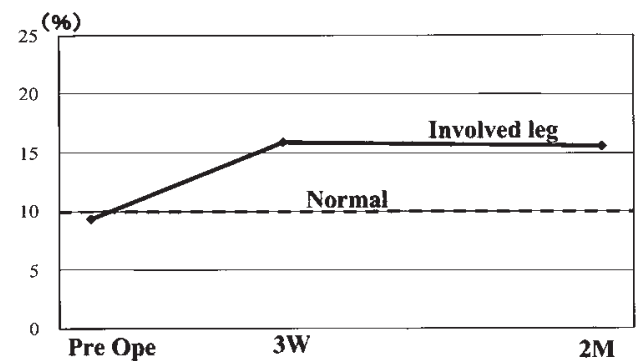

Fig. 10 Double support duration (\% cycle) Double support duration prior to RAO was lower than the normal average value. Three weeks postoperatively, it increased at a rapid rate until 2 months post $\mathrm{RAO}$ before gradually attaining the normal average value.

(according to the JOA score). Postoperatively, the CE angle was 30 degrees and AHI was 85.7\% (Fig. 8). Single support duration preoperatively was $42 \%$, which decreased to $29 \% 3$ weeks post RAO before attaining the normal average value (Fig. 9). Double support duration prior to RAO was lower than the normal average value. The increasing rate was high 3 weeks postoperatively. Although a gradual advance towards the normal average value was observed, after 2 months, it was still higher than the value recorded prior to RAO. (Fig.10).

\section{Discussion}

Single and double support duration prior to RAO showed no significant difference when compared with the normal average value; however, postoperative single support duration increased while double support duration decreased before gradually attaining the normal average value again. Single support duration attained normal average value in most patients within 1 year post RAO, while double support duration attained the normal average value within 6 months post RAO.

Murray et al. ${ }^{3)}$ reported that the duration of the stance phase was shorter on the pain than on the sound side. The gait characteristics observed in the patients until 3 weeks postoperatively were similar to those observed in patients with arthropathy. The gait characteristics observed in patients with no hip pain showed no significant difference with a normal average value in healthy humans in spite of the Trendelenburg's sign demonstrated by muscle weakness in these patients. Considering this, it was possible that the hip pain was more important in comparison to other factors such as muscle weakness. Murray et al." reported that single and double support duration are correlated with the grade of hip pain and can be used as an index of severe pain. As observed in this study, single support duration prior to RAO was unchanged when compared with the normal average value whereas double support duration prior to RAO showed increasing values. Therefore, it is possible that the patients had some hip pain prior to RAO although they did not complain of $i t^{29)}$.

Three weeks postoperatively, the pain may have been accentuated while walking. Subsequently, the walking pattern gradually attained the normal average value. This might have been possible due to a gradual decrease in hip pain while walking, as it approached a normal walking pattern. Gait 
characteristics normalized with the disappearance of hip pain post RAO. A study on early weightbearing post RAO was performed in our hospital. Functional evaluation of the gait pre- and post RAO have been reported ${ }^{1}$, and gait characteristics were observed to improve within 1 year post RAO. Based on our study, we believe that early weight-bearing does not affect gait characteristics post RAO.

\section{Conclusion}

1) Gait pattern in patients post RAO was evaluated.

2) Single support duration decreased and double support duration increased in all the patients post RAO.

3) Gait characteristics were observed to be different in the early and advanced stages of OA prior to RAO.

4) Gait characteristics normalized within 1 year post RAO, suggesting that early weight-bearing does not affect gait characteristics post RAO.

\section{References}

1) Endo, H., et al.: Gait analysis after RAO for dysplasia. J. Orthop. Sci., $8: 762-771,2003$.

2) Gore, D. R., et al.: Walking Patterns of Men with Unilateral Surgical Hip Fusion. J. Bone Joint Surg., 57-A : 759-765, 1975.

3) Murray, M. P., et al.: Walking Patterns of Normal Men. J. Bone Joint Surg., 43-A : 923-938, 1964.

4) Murray, M.P., et al.: Walking Patterns of Patents with Unilateral Hip Pain Due to Osteo-Arthritis and Avascular Necrosis. J. Bone Joint Surg., 53-A : 259-274, 1964.

5) Nakamura, S., et al.: Combined intertrocanteric valgus and rotational acetabular osteotomy. Clin. Orthop., 384 : 176-188, 2001.

6) Nakamura, S., et al.: Primary osteoarthritis op the hip in Japan. Clin. Orthop., 241 : 190-196, 1989.

7) Ninomiya, S., Tagawa, H.: Rotational acetabular osteotomy for the dysplastic hip. J. Bone Joint Surg., 66-A : 430-436, 1984.

8) Ninomiya, S.: Rotational acetabular osteotomy for severely dysplastic hip in the adolescent and adult. Clin. Orthop., $247: 127-137,1989$.

9) Romano, C. L., et al.: Analysis of the gait of adults who had residua of congenital dysplasia of the hip. J. Bone Joint Surg., 78-A : 1468-1479-436, 1996. 
〈和文抄録〉

\title{
早期荷重を行っている $\mathrm{RAO}$ 症例における歩行解析の検討
}

\author{
佐賀大学整形外科 \\ 植木里紀・重 松 正 森 \\ 本岡勉 - 佛淵 孝夫
}

当院では, クリティカルパスを用いて寛骨臼回転骨 切り術（以下 RAO）後の早期荷重, 早期退院を行つ ている. 今回 1999 年より 2003 年 10 月までに RAO を施行した 116 例 125 股のうち経過を観察できた 27 例に歩行解析を行い, 歩行状態に与える影響を検討し た.

方法としては，ゲイトスキャン 8000 （ニッタ株式 会社製）を用いて，入院後，術後 3 週・ 2 力月 ・半年 1 年以上の各時期にセンサシートの上を自由歩行して もらい，約 5 秒間測定した。今回は特に時間因子であ
る単脚支持率・両脚支持率に注目し検討した.

術前の $\mathrm{RAO}$ 症例患者の, 単脚支持率は健常者と変 わらず，両脚支持率は健常者より増加していた。 術後 3 週では単脚支持率は減少, 両脚支持率は増加した. 術後 1 年では単脚支持率, 両脚支持率ともに健常者レ ベルへ改善した.

以上より，RAO が臼蓋形成不全症患者の歩行状態 に与える影響は良好であった。 また，早期荷重を行っ てもその後の歩行状態に影響を及ぼすことはないと考 えられた. 